\title{
Ethical Problems in Communication and Law At The Creation of the Survey's Ethics Board
}

\author{
Nanang Trenggono
}

Faculty of Social and Political Science, Universitas Lampung, Indonesia, Email: trenggononanang@gmail.com

\begin{tabular}{|c|c|}
\hline Article Info & Abstract \\
\hline $\begin{array}{l}\text { Keywords: } \\
\text { Ethics in Communication, Ethics in } \\
\text { the Law, Ethics Board. } \\
\text { How to cite: } \\
\text { Nanang Trenggono, "Ethical } \\
\text { Problems in Communication and } \\
\text { Law At The Creation of the } \\
\text { Survey's Ethics Board" Fiat } \\
\text { Justisia: Jurnal Ilmu Hukum 14, } 2 \\
\text { (2020):189-202. } \\
\text { DOI: } \\
\text { 10.25041/fiatjustisia.v14no2.1931 }\end{array}$ & $\begin{array}{l}\text { Public reports of misconduct survey institution in the } \\
\text { local leader election arrangement, put the Komisi } \\
\text { Pemilihan Umum Provinsi (KPU) provinsi or the } \\
\text { Province's General Election Commission has an } \\
\text { optional authority, can form an ethics council or } \\
\text { submit to the survey association. Then it became a } \\
\text { matter, because of the verdict is "a half truth," } \\
\text { potentially damaging ego or the pride of another. } \\
\text { Ethics council establishment as the enforcement of } \\
\text { institutional authority should begin with } \\
\text { clarification as a consequence of ethics in } \\
\text { communication, and it requires technical guidance } \\
\text { from The National Election Commission to fulfill the } \\
\text { ethical weight of the law. But there is a conflict of } \\
\text { interest when issues are refered to the survey } \\
\text { association. When on trial, on the Dewan } \\
\text { Kehormatan Penyelenggara Pemilu (DKPP) or the } \\
\text { Honorary Election Board, the decision is evident } \\
\text { contradictions; in consideration of appreciation, } \\
\text { amar sanctioned the warning. }\end{array}$ \\
\hline
\end{tabular}

\section{A. Introduction}

The selection of Kepala Daerah dan Wakil Kepala Daerah (Pilkada) or regional heads and deputies was held simultaneously. The municipal and veckage elections in the Lampung area have been held since 2015, 2017, 2018 and again in 2020. The selection of local chiefs and individual deputies has been held since 2005, it grows into a simultaneous election in 2015, accompanied by the growth of national and provincial survey societies, that is Lembaga Survei Indonesia (LSI), Saiful Mujani Research and Consulting (SMRC) or Charta Politika Indonesia. In Lampung, it appears in between Rakata Institute, Sai Wawai Intitute, Lembaga Survei Lampung (LeSLa), and Kuadran. The presence of the survey society contributed to "the color" of the 
voting arragements that had previously been limited to legislative and presidential elections.

The Election of Governor and Deputy Governor in the Lampung of 20192024 was carried out on June 27, 2018, surveyed by SMRC, Charta Politika and Rakata Institute. All 3 (three) had already done the survey and published the results without signing up to the General Election Commision of Lampung in accordance with the applicable regulations of the law.

This indicates a potential of offense done by these survey institutions. However, this experience did not give an example, action, and control towards survey institution that has allegedly violated a norm in a general or local leader election. Another matter to consider is when the Rakata Institute is communicating widely their survey results, has ignored the presence of mainstream local news and online media, without inviting present on their release, and so is a conflict of interest and sentiment. Accordingly, in addition to breaking the rules of law there is also breaking of ethics in communication.

The abuses were reported by people to the General Election Commision of Lampung, to decide wether to form an ethics council, and not turn the matter over to the survey society's associations. It is got a reaction from the Rakata Institute by reporting the Election Commission's Honor Council or the Dewan Kehormatan Penyelenggara Pemilu (DKPP). Results of trial of the DKPP has decided that a written warning be sanctioned to KPU Lampung, but it is in their judgment to appreciate the General Election Commission of Lampung for the initiation of an unprecedented board of ethics in Indonesia. Based on the the above description, two research question arises: What is the ethical problem in communication with the creation of the survey's board of ethics? and What is the problem with ethics in the law at the creation of the survey's ethics board?

This post factum research reviewing events that have taken place, because it contains an axiological dimension that strenghthens election as a process of democracy in Indonesia. In this case, understanding the formation of the survey board of ethics under the arrangements the elections of Governor and Deputy Governor of Lampung period 2019-2024, that feature reseachers as the principal instruments. ${ }^{1}$

The research built verstehen to find meaning of an event in order to be fully explained. ${ }^{2}$ Also use epoche methods with a scientific awareness not skeptical of reality, it merely suspend assumptions (judgments) that embedded in reality. And so in the event of the creation of the survey board of ethics, more likely it correlates one reality with another, without judging by one point of

\footnotetext{
${ }^{1}$ Djam'an Satori \& Aan Komariah, Metodologi Penelitian Kualitatif (Bandung: Afabeta, 2009), 78.

${ }^{2}$ Lexy J. Moleong, Metodologi Penelitian Kualitatif (Bandung: Remaja Rosdakarya, 2002), 910.
} 
view. ${ }^{3}$ According to experience, researcher are constructions an interpretation of ethical problems in communication and the law.

\section{B. Discussion}

The regulation that arrange on survey institution as a political communication act in election is Law No. 10 Year 2016 on the Election of Governor, Regent/Mayor, and PKPU No. 8 Year 2017 on Socialization, Voter's Education, and Society's Participation in the Election of Governor and Regent/Mayor. Article 51 of General Election Commission Regulation No. 8 Year 2017 stated that:

1. The society's report towards survey or voting poll execution in election's quick count could be delivered to Province General Election Commission/Komisi Independent Pemilihan (KIP) or Election Independent Commission Aceh or Regency General Election Commission/Election Independent Commission.

2. In action of society's report, the General Election Commission/Election Independent Commission Aceh and Election Independent Commission Aceh or Regency General Election Commission/Election Independent Commission can form an ethical board or hand the case to association of survey institution for evaluation on alleged ethical violation by survey and quick count organizer. This regulation is main focus of this research. In 2018's Governor Election, General Election Commission of Lampung responded and took a different decision towards the society's report on an alleged offense by the survey institutions, (1) formed an ethical board to evaluate and (2) handed the case to association of survey institution to solve internally. Both of these decision options have been taken and set apart by the KPU Lampung.

\section{Ethical Problems in Communication}

There are two ethical problems in communication, which is the ethics of the survey society in communication, and the election ethics of communication in the creation of the survey's board of ethics. In communication, media mimetisme could be a dilemma in spreading information to the public from communication ethic's factor. Mimetisme is a sudden passion that rides the media as if this particular then is in urgent to cover the news because another media is the reference. The news cover does not bother about the impact to a different importance. It also does not calculate a parting effect, which is covering a theme really is describing a situation that is hiding another important event. ${ }^{4}$

\footnotetext{
${ }^{3}$ Donny Gahral Adian, Pengantar Fenomenologi (Depok: Koekoesan, 2010), 13-20.

${ }^{4}$ Haryatmoko, Etika Komunikasi: Manipulasi Media, Kekerasan dan Pornografi, (Yogyakarta: Kanisius, 2007), 19-23.
} 
Therefore, communication ethics is a research theme that is importance in democracy, including local leader election. There are 3 (three) dimensions of communication ethics: (1) dimension that correlates directly with the communication actor's behaviour, politics, normative-ethics, deontology or morality based on obedience to the law, (2) dimension of facility in correlation to regulation, and dimension on policy involving the value of democracy, freedom of expression, freedom of press, and public rights to receive correct information. ${ }^{5}$ Deontology dimension has a similarity with ethical normative perspective. Ethic-normative tries to find a general standard upon good and bad behaviour. ${ }^{6}$

Even though there is such provision, the implementation is so different. On April 2, 2018, Rakata Institute released survey result of 2018 Lampung Governor Election. A month prior, Charta Politikal also released on March 20, 2018 continued by SMRC on March 26, 2018. However, these 3 (three) did not register themselves to Lampung's General Election Commission. The action done by these institutions are in contrary with Article 132 Law No. 10 Year 2016 that stated:

a. Survey and quick count organizer are obligated to report the institution's status or Registered Letter of Statement.

b. The Province or Region General Election Commission established institutions that perform surveys in a quick count. ${ }^{7}$

Rakata Institute invites 7 (seven) medias which are Tribun Lampung, and Radar Lampung TV. Rakata did not invite one main newspaper media of Lampung, Lampung Post. Therefore, Lampung Post daily critique to Rakata Institution. The particular choice in media is contradictory on terms of its function to socialize politics, bearing in mind that adolescence receives their first knowledge on politics from the media. ${ }^{8}$

Besides that, the limitation of media invitation supports the idea of a democracy shift from public importance towards privacy and beneficial orientation..$^{9}$ If it is reviewed from the political communicator, it can be said that communication by Rakata Institution, SMRC and Charta Politika is a form of activist political communication and divided into 2 (two) categories, (1) As a speaker for organizational interests and (2) as an opinionated party to

\footnotetext{
${ }^{5}$ Ibid., 43-51.

${ }^{6}$ Kismiyati El Karimah \& Uud Wahyudin, Filsafat \& Etika Komunikasi: Aspek Ontologis, Epistemologis dan Aksiologis dalam Memandang Ilmu Komunikasi (Bandung: Widya Padjadjaran, 2010), 61.

${ }^{7}$ Law Number 10 of 2016 concerning Second Amendment to Law Number 1 of 2015 concerning Stipulation of Government Regulations Substituting Law Number 1 of 2014 concerning Election of Governors, Regents and Mayors to become Laws.

${ }^{8}$ Karim Suryadi, "Media Massa dan Sosialisasi Politik: Perspektif Teori Belajar Sosial," Jurnal Ikatan Sarjana Komunikasi Indonesia, Komunikasi Politik, IV, No. October (1999): 59-73.

9 Gusti N. Putra, "Demokrasi dalam Komunikasi Terprivatisasi," Jurnal Ikatan Sarjana Komunikasi Indonesia, Pers Indonesia Era Transisi VI, No. November (2001): 84-97.
} 
support and impact or form particular political interests. Activist as political actors mainly have a large impact and comes from a political party or mass organization that are related to a non permanent commitment. This is either based on idealism or certain interests. The purpose of this activity is a campaigning to victory. ${ }^{10}$

The assumption came true, the survey result released by Rakata Institution caused such polemic. From then, protest came from Aliansi Pers Peduli Demokrasi or the Press Alliance is Concerned for Democracy. The protest demands for the director of Rakata Institute to withdraw his statement in Face book that is valued as demeaning the profession of reporters/journalists. News titled "Direktur Rakata Bisa dijerat UU ITE" wrote that the Press Awareness Alliance reported Rakata Institute's Director towards Regional Police of Lampung. ${ }^{11}$ The news eventually became a headline. ${ }^{12}$

The Badan Pengawasan Pemilihan Umum (Bawaslu) or the Election Supervisory Agency's leader highlights the research method and income source. This is due to understand Rakata Institute's neutrality in executing its survey. ${ }^{13}$ The head of Lampung's Information Commission valued that Rakata had potentials to violate General Election law No. 14 Year 2008 on Public Information Transparency. The Head of Indonesia Broadcasting Commission for Lampung Region stated, "Supposedly, Rakata should have invited all media since the information upon future leaders should be spread widely." ${ }^{14}$ The transition era on democracy has changed the communication pattern from previous era that was more aligned and interactive. ${ }^{15}$

The society's reaction came to surface through an official report from General Election Commission of Lampung on April 16, 2008 by the Youth Network of the Republic of Indonesia's Presidium Coordinator or the Koordinator Presidium Jaringan Pemuda Republik Indonesia (JAPRI). This network requests an establishment of an ethical board regarding to the release of Rakata Institute. The report was discussed in a plenary meeting on April 17,2018 . The plenary meeting then agreed to form an ethical board on Rakata Institute as a survey institute. In communicational contribution on development theory, this is a form of interactive communication model. The communication is no longer one way, every participant has a part in the

\footnotetext{
${ }^{10}$ Adhi Iman Sulaiman, "Komunikasi Politik dalam Pilkada antara Das Sollen dan Das Sein," Jurnal Observasi: Kajian Komunikasi dan Informatika 6, No. 1 (2008): 41-58.

11 “Direktur Rakata Bisa Dijerat UU ITE," Lampung Post, April 25, 2018.

12 “Kalau Enggak Benar, Bisa Diindikasi Tidak Netral,"Lampung Post, April 23, 2018.

13 “Direktur Rakata Diduga Melanggar Netralitas ASN, ”Radar Lampung, April 25, 2018.

14 “Harusnya Terbuka, Tidak Ada Diskriminasi,"Lampung Post, April 16, 2018.

15 Rusdi Muchtar, "Peranan Penelitian Komunikasi dalam Pembangunan Nasional pada Milenium Ketiga," Jurnal Ikatan Sarjana Komunikasi Indonesia, Industri Pers dan Prospek Kebebasannya V, No. Oktober (2000): 84-105.
} 
process of communication. In terms of development participation concept is the main focus. ${ }^{16}$

Afterwards a decision letter on an ethical board establishment for Rakata Institute was made on April 23, 2018 which was revised on 2018 with members consisting of Nanang Trenggono (Chairman of the Election Commission of Lampung), Wan Abbas Zakaria (academician), Mustofa Usman (expert on surveys), HS Tisnanta (expert on surveys) and Robi Cahyadi Kurniawan (academician). From the coverage of media, Rakata Institute's issue has exposed further that survey is more than just a scientific research. Actually, this is correlated with the existence of media. The press' works that are based on idealism on commercial orientation enables media's optimization on community development. However, keeping in mind that the press struggles to stay neutral and tend to bias in value, the community development is underwhelming. Facts show that only objective press could effectively implement their function as community empowerment media. ${ }^{17}$

The establishment of an ethics board must meet the ethics in its communication process. Because of the performance of institutional functions, it is inevitable to do something to society. In words, actions, or decisions. Communication can be a failure, because others feel desperate or threatened, to provoke a rash response, a second order hurts one's ego, a thing that seemed naturally to maim the pride of another, to disagree is considered a reproach, a truth exists in the wrong time and place, or is still half true. We do not know all the effects of words, actions, or decisions that occur to the people or others, both positive and negative. ${ }^{18}$

The decision to form an ethics council would be a perfect measure if the procedure were made with the protection of the law and the compliance of a sense of justice. One of the strategic procedures, the process of shaping it began by providing sufficient space for survey agencies to clarify public reports. The ethical board works through technical direction by collecting data such as media news, document on the release, and video footage of release from start until current. Besides that, release documents handed by journalist either invited or not in the release are requested. Interviews are also submitted. After review, a court should be held. It is set that there will be a 3 (three) time court. The first 2 (two) are examinations and last is judgment hearing. In these 3 (three) courts, Rakata Institute was absent.

\footnotetext{
16 Andy Corry Wardhani, "Kontribusi Komunikasi pada Teori Pembangunan," Jurnal Komunikasi Mediator 3, No. 2 (2002): 259-265.

${ }^{17}$ Novel Ali, "Pers Objektif, Media Pemberdayaan Masyarakat yang Efektif," Jurnal Ikatan Sarjana Komunikasi Indonesia, Komunikasi dan Demokratisasi I, No. Juli (1998): 13-23.

18 Thomas R. Nilsen, "Ethical Problems in Communication," In Sanford Weinberg, ed, Messages: A Reader in Human Communication (New York: Random House, Inc, 1980): 2431.
} 
The ethical board performed examination and judgment hearing, the board agreed to do a method review done in 3 (three) periods of surveys. From the point of method substance, (1) the sample collection from regional/city to sub-district, from sub-district to village (office), and from village (office) to respondent are unclear. (2) The distribution of sample that decides error standard which is a different sample proportion that decides different errors standard for each future respondent is unclear. (3) There is flowchart of gained sample ratified in 2 (two) stages; first, the polling station or Tempat Pemungutan Suara (TPS) in region/city and respondent in the polling stations. But in reality, the amount of polling station was never settled by the general election's organizer. Eventually, the ethical board concluded and decided that the survey result release by Rakata Institute is not credible either administratively or substantively. ${ }^{19}$

In the midst of ethical board of Rakata Institute's court, the Lampung's General Election Commission received a report from the Lampung Society Coalition for a Transparent General Election or the Koalisi Rakyat Lampung untuk Pemilu Bersih (KRLUPB) on May 4, 2018 report and demand to establish an ethical board. This report marks the establishment of ethical board, not statistics information but a process of public communication. ${ }^{20}$

The Lampung General Election Commission gave the same reaction to all society's report on violation allegation by Rakata Institute by performing a discussion on a report in the plenary meeting. After the plenary meeting, the Lampung General Election Commission agreed that the report on Charta Politika and SMRC should be handed to the association where these surveys are a part of which the Perhimpunan Survei Opini Publik (PERSEPI) is or the Association of Public Opinion Survey through a letter on May 22, 2018. PERSEPI replied on 14 June, 2018, concluding that in the survey release both Charta Politika and SMRC did not indicate any violation.

\section{An Ethical Problem Within the Law}

Ethical problem in law at the creation of the Rakata Survey Board, may refer to the purpose of a constitution which contains an ethical dimension which is: ${ }^{21}$

a. To impose restrictions and supervision on political rule;

b. To free power from the control of rulers, and establish the limits of their power.

\footnotetext{
${ }^{19}$ A copy of the decision of Rakata Institute's Ethics Board Nomor 4/Kpts-Dewanetik/V/2018 May 14, 2018.

${ }^{20}$ Priza Andermando Purba, "Transformasi Struktural Komunikasi Publik untuk Pembangunan Nasional," Jurnal Dialog Kebijakan Publik, Paradigma Baru dan Penguatan Kelembagaan Komunikasi, Edition May 20, (2016): 23-29.

${ }^{21}$ Dahlan Thaib, Jazim Hamidi \& Ni'matul Huda, Teori dan Hukum Konstitusi, Cetakan ke-11 (Jakarta: Raja Grafindo Persada, 2013), 23.
} 
To uphold the constitution, it is necessary to introduce the law as a means of maintaining order (conservative), and the law as a means to build a society of culture to get ahead. ${ }^{22}$ The Lampung General Election Commission decision is in accordance with the regulation, that for a society report on a survey, the Province General Election Commission has the authority to form an ethical board or hand over the issue to a survey institution association. These choices contains dilemma in the law ethics and is uneasy to implement. However, the Lampung General Election Commission agrees to execute these choices that are provided in the General Election Commission regulation.

Consequences on Lampung General Election Commission's decision are reviewed through the report from Rakata Institute towards the Dewan Kehormatan Penyelenggara Pemilu (DKPP) or the Election Organization Ethics Council. Decision to form an ethical board is reviewed in a court for allegation of ethical code violation in a General Election. This is relevant to the essence of management crisis in communication that has no guide yet an early estimation to face what is unexpected through quick and effective response. Therefore, the needed guide is not detailed and formal content, yet a handbook that guides to a wider point, because communication management of crisis is disciplinary and multifunctional. ${ }^{23}$

Dilemma in ethics happened due to a democracy essence that in institution of democracy system is equaled by a very basic element which is open rivalry for participants. In the democracy system, conflict could never be erased. Through the process of institutionalizing, democracy conflict could only be handled. Thus, the essence of democracy can be see from the side of conflict management system, where the end result that happen will fully depend on the participant's action in the provided institution's frame. Neither one of the conflict actors has the power to control what will happen. The conflict end result is unknown by the conflict perpetrator since the consequence from their actions depend on the political strength of each actions. ${ }^{24}$

On June 4, 2018, DKPP's Ethical Assembly performed a court on alleged violation of ethical code, establishment of Rakata Institute's ethical board. In the court, DKPP's Ethical Assembly gave 2 (two) critical question that must be followed up and revise in the court resume by Head of the Lampung General Election Commission, which are (a) did the Lampung General Election Commission established the technical guidance in the formation of an ethical board? And (b) what are criteria ruled by Lampung General Election

\footnotetext{
${ }^{22}$ Mohammad Mahfud MD, Membangun Politik Hukum, Menegakkan Konstitusi (Jakarta: Raja Grafindo Persada, 2010), 28.

23 Andre A. Hardjana, "Manajemen Komunikasi dalam Krisis," Jurnal Ikatan Sarjana Komunikasi Indonesia, Manajemen Krisis II, No. Oktober (1998): 12-24.

${ }^{24}$ Nasikun, "Reformasi Jalan Berliku Menuju Transisi Demokrasi," Jurnal Ilmu-Ilmu Sosial: Melacak Arah Reformasi, No. 37/XX/ (1998): 3-13.
} 
Commission in forming and ethical board? The court was executed once. Afterwards, the Lampung General Election Commission made an official clarification through a written revision towards the critical question from DKPP's Ethical Assembly. In reality, Lampung General Election Commission had published a technical guidance that underlined the formulation of survey institution's regulation in accordance to the law and General Election Commission Regulation.

However in the DKPP Court, it is acknowledged that in the plenary meeting, technical guidance in formation of an ethical board was not taken into the judgment consideration. The reason is that this procedure follows the report on a violation by a survey institution as stated in the mutatis mutandi technical guidance equal to the General Election Commission Regulation. ${ }^{25}$

This particular guidance adopted 7 (seven) General Election Commission Regulation. Based on the DKPP's Ethical Assembly, Lampung General Election also did a completion towards the court's resume revision which is criteria of survey institution's violation on an ethical board formation. Then, it proceeds by formulating criteria on the formation of an ethical board. The criteria are actually in existence, yet it is unwritten in the plenary meeting report prior. However, DKPP's Assembly insists in order to fulfill principle of legal certainty. These criteria are the grounds of forming an ethical board of Rakata Institute (See table 1 below):

Table 1: Criteria of Establishing Ethical Board or Transfer to Association

\begin{tabular}{|c|l|}
\hline No. & \multicolumn{1}{|c|}{ Indicators } \\
\hline 1. & $\begin{array}{l}\text { Has not registered to the General Election Commission of } \\
\text { Lampung Province. }\end{array}$ \\
\hline 2. & An existing report from society includes an electronic Citizen ID. \\
\hline 3. & $\begin{array}{l}\text { Society's report should be maximum of 7 (seven) calendar days } \\
\text { after survey release. }\end{array}$ \\
\hline 4. & Society's report provides complete evidence. \\
\hline 5. & $\begin{array}{l}\text { A massive polemic that disturbs the Election's conducive } \\
\text { situation. }\end{array}$ \\
\hline 6. & Potentially beneficial and damaging participant. \\
\hline 7. & Potentially interfering stages of election \\
\hline 8. & $\begin{array}{l}\text { Survey and release performed after establishment of governor } \\
\text { and deputy governor candidates. }\end{array}$ \\
\hline 9 & Survey and release performed during campaign. \\
\hline
\end{tabular}

25 A copy decree of Lampung Province Election Commission Number 21/HK.04.1Kpt/18/Prov/VIII/2017 August 24, 2017 regarding the Technical Guidelines for the Implementation of Socialization and Community Participation in the Election of the Governor and Deputy Governor of Lampung in 2018. 
The DKPP's judgment in forming Rakata Institute's ethical board for allegation of ethical code violation is giving appreciation towards ethical board establishment. This is also a warning towards Nanang Trenggono, the Head of Lampung General Election Commission. In correlation towards DKPP's decision, the Head of Lampung General Election Commission, asked for clarification and explanation through a formal letter towards Head of DKPP. However, DKPP state that the judgment of DKPP is final and binding. 26

In the DKPP's verdict that although KPU Lampung has established a technical guide on performing social techniques, and community participation, however it is proper that decision should be accompanied by regulation that regulates the procedures and mechanisms of the establishment of the ethics council as well as the ordinance of examination of alleged violations by the survey society. ${ }^{27}$ From the verdict of DKPP, on ethical problem revealed in the law for the creation of the Rakata Survey Board of Ethics:

Firstly, the General Election Commission Regulation adopted completely from the law that in midst of report on violation allegation in survey, where Province General Election Commission can form an ethical board or hand over issue to a survey institution association which are optional and both ways can be executed at once since it is regulated in the Province General Election Commission technical guidance, equal to the law and the Province General Election Commission regulation. Any measures of survey violations that could result in the creation of a board of ethics or could be turn over to the association of the survey society, became an ethical matter in the law.

Secondly, survey institution tends to hand over issue by settling it with an asserted mechanism on ethical code survey institution. This is considered normal, because the process of communication is performed by person who is an important part with pride and integrity. ${ }^{28}$ Examples of survey institution association are, SMRC and Charta Politika under PERSEPI. Rakata Institute under ALSHCI (Asosiasi Lembaga Survei \& Hitung Cepat Indonesia) on March 12, 2018. The head of ALSHCI is the same person who is the Director of Rakata Institute. If Rakata Institute as a survey institution is handed over to its association, in this case ALSHCI, it will implicate conflict of interests.

\footnotetext{
${ }^{26}$ The Report of Lampung Province Governor and Deputy Governor Election 2018 by the Election Commission of Lampung Province.

${ }^{27}$ A copy of decision of the Election Organizer Honorary Board (DKPP) No. 117/DKPP-PKEVII/2018, July 6, 2018.

${ }^{28}$ Soeganda, Priyatna, "Pengantar ke Kajian Ilmu Komunikasi," Jurnal Komunikasi dan Informasi, Dunia Komunikasi Dunia Kita, Special Edition in September (2005): 2-26.
} 
Thirdly, the review in General Assembly of DKPP's court also reveals an ethic dilemma in an ethical board formation. In one side, DKPP's judgment appreciates Lampung General Election Commission that had formed an ethical board. In another side, DKPP decides to warn the Head of Lampung General Election Commission. The formation of a survey institution's ethical board can be done if there is a regulation of General Election Commission of the Republic of Indonesia provided so and applied through out the provinces.

It is clear that an act is legal not automatically means measuring up to ethics standards, or to-the contrary, a so-called illegal act does not have to come about by itself it goes against ethical standards. ${ }^{29}$ Here the election organizer should have consciousness not just following the rule of law, but also following the rule of ethics. ${ }^{30}$

It may be concluded that ethical testing differs from that of law or norm or law code. Ethical testing rests on virtues of a dubious character, of good judgment and of non-compliance with constitutional law authority and enforcement materials aspects. In the context of the election, it refers to the ethics of the election organizer. ${ }^{31}$

\section{Conclusion}

Based on results and research discussions may be formulated the following conclusion: Ethical problems in communication are inherent in the survey society because of its activities ignoring regulations and are not transparent and fair when it publicizes the results of its survey. However, ethical problems in communication with the establishment of ethics councils are taking place because it does not begin by providing sufficient space for the survey society to do clarification; An arrangement for survey violations, it's an optional authority, to establish a board of ethics or submit to survey association, contains ethical problems in the law; first, associations can turn into legal protection and thus contain a conflict of interest if authorized to resolve survey violations; and second, the creation of a board of ethics should be equipped with the technical guidelines from the Republic of Indonesia Election Commission, in order to meet common criteria to implement simultaneously.

From the research conclusion can be formulated the following two recomendations: The technical regulation's formulation is righteously to be

\footnotetext{
${ }^{29}$ Jimly Asshiddiqie, Peradilan Etik dan Etika Konstitusi, Perspektif Baru tentang Rule of Law and Rule of Ethics \& Constitutional Law and Constitutional Ethics (Jakarta: Sinar Grafika, 2014), 98.

30 Jimly Asshiddiqie, Menegakkan Etika Penyelenggara Pemilu (Jakarta: Raja Grafindo Persada, 2013) 39.

${ }^{31}$ Irvan Mawardi, Dinamika Sengketa Hukum Administrasi di Pemilukada, Mewujudkan Electoral Justice dalam Kerangka Negara Hukum Demokratis (Yogyakarta: Mahakarya Rangkang Offset, 2014), 272.
} 
executed by a national organizer to have it applied in Indonesia; technically, the regulation arrangement shoulf formulate articles that would support authority organizers meet their expectation including laws that protects offender survey activities.

\section{References}

Adian, Donny Gahral. Pengantar Fenomenologi. Depok: Koekoesan, 2010. Ali, Novel. "Pers Objektif, Media Pemberdayaan Masyarakat yang Efektif. " Jurnal Ikatan Sarjana Komunikasi Indonesia, Komunikasi dan DemokratisasiI, No. July (1998): 13-23.

Asshiddiqie, Jimly. Menegakkan Etika Penyelenggara Pemilu. Jakarta: Raja Grafindo Persada, 2013.

Asshiddiqie, Jimly. Peradilan Etik dan Etika Konstitusi, Perspektif Baru tentang Rule of Law and Rule of Ethics \& Constitusional Law and Constitusional Ethics. Jakarta: Sinar Grafika, 2014.

Decision of Rakata Institute's Ethics Board Nomor 4/KptsDewanetik/V/2018 May 14, 2018.

Decision of the Election Organizer Honorary Board (DKPP) No. 117/DKPPPKE-VII/2018, July 6, 2018.

Decree of Lampung Province Election Commission Number 21/HK.04.1Kpt/18/Prov/VIII/2017 August 24, 2017 regarding the Technical Guidelines for the Implementation of Socialization and Community Participation in the Election of the Governor and Deputy Governor of Lampung in 2018.

Hardjana, Andre A. "Manajemen Komunikasi dalam Krisis." Jurnal Ikatan Sarjana Komunikasi Indonesia, Manajemen Krisis II, No. October (1998): 12-24.

Haryatmoko. Etika Komunikasi: Manipulasi Media, Kekerasan dan Pornografi, Yogyakarta: Kanisius, 2007.

Karimah, Kismiyati El \&Wahyudin, Uud. Filsafat \& Etika Komunikasi: Aspek Ontologis, Epistemologis dan Aksiologis dalam Memandang Ilmu Komuikasi. Bandung: Widya Padjadjaran, 2010.

Law Number 10 of 2016 concerning Second Amendment to Law Number 1 of 2015 concerning Stipulation of Government Regulations Substituting Law Number 1 of 2014 concerning Election of Governors, Regents and Mayors to become Laws.

Mahfud MD, Mohammad. Membangun Politik Hukum, Menegakkan Konstitusi. Jakarta: Raja Grafindo Persada, 2010.

Mawardi, Irvan. Dinamika Sengketa Hukum Administrasi di Pemilukada, Mewujudkan Electoral Justice dalam Kerangka Negara Hukum Demokratis (Yogyakarta: Mahakarya Rangkang Offset, 2014). 
Moleong, Lexy J. Metodologi Penelitian Kualitatif (Bandung: Remaja Rosdakarya, 2002)

Muchtar, Rusdi. "Peranan Penelitian Komunikasi dalam Pembangunan Nasional pada Milenium Ketiga," Jurnal Ikatan Sarjana Komunikasi Indonesia, Industri Pers dan Prospek Kebebasannya V, No. October (2000): 84-105.

Nasikun. "Reformasi Jalan Berliku Menuju Transisi Demokrasi." Jurnal Ilmu-Ilmu Sosial: Melacak Arah Reformasi, No. 37/XX/I (1998): 3-13.

PKPU No. 8 Year 2017 on Socialization, Voter's Education, and Society's Participation in the Election of Governor and Regent/Mayor.

Priyatna, Soeganda. "Pengantar ke Kajian Ilmu Komunikasi." Jurnal Komunikasi dan Informasi, Dunia Komunikasi Dunia Kita, Sepecial Edition in September (2005): 2-26.

Purba, Priza Andermando. "Transformasi Struktural Komunikasi Publik untuk Pembangunan Nasional." Jurnal Dialog Kebijakan Publik, Paradigma Baru dan Penguatan Kelembagaan Komunikasi, Edition May 20, (2016): 23-29.

Putra, Gusti N. "Demokrasi dalam Komunikasi Terprivatisasi." Jurnal Ikatan Sarjana Komunikasi Indonesia, Pers Indonesia Era Transisi VI, No. November 2001: 84-97.

Satori, Djam'an \& Komariah, Aan. Metodologi Penelitian Kualitatif. Bandung: Afabeta, 2009.

Sulaiman, Adhi Iman. "Komunikasi Politik dalam Pilkada antara Das Sollen dan Das Sein." Jurnal Observasi: Kajian Komunikasi dan Informatika 6, 1 (2008): 41-58.

Suryadi, Karim. "Media Massa dan Sosialisasi Politik: Perspektif Teori Belajar Sosial." Jurnal Ikatan Sarjana Komunikasi Indonesia, Komunikasi Politik IV, No. Oktober (1999): 59-73.

Thaib, Dahlan, Hamidi, Jazim \& Huda, Ni'matul. Teori dan Hukum Konstitusi, Cetakan ke-11. Jakarta: Raja Grafindo Persada, 2013.

The Report of Lampung Province Governor and Deputy Governor Election 2018 by Book Report of the Election Commission of Lampung Province.

Wardhani, Andy Corry. "Kontribusi Komunikasi pada Teori Pembangunan," Jurnal Komunikasi Mediator 3, 2 (2002): 259-265.

“Harusnya Terbuka, Tidak Ada Diskriminasi," Lampung Post, April 16, 2018. "Kalau Enggak Benar, Bisa Diindikasi Tidak Netral,"Lampung Post, April 23, 2018.

“Direktur Rakata Bisa Dijerat UU ITE,” Lampung Post, April 25, 2018.

"Direktur Rakata Diduga Melanggar Netralitas ASN, "Radar Lampung, April $25,2018$. 
